\title{
How Buddhism Plays a Role through Victim-Offender Mediation in Handling the Challenges of Crime in China's Tibet
}

\author{
Lu Feng
}

School of Law, Sichuan University, Chengdu 610207, China; fenglu@scu.edu.cn

\begin{abstract}
Religion plays a significant role in the way Western societies respond to criminal offenses. However, the research on how religion plays a role in handling the challenges of crime in non-Western countries is lacking. In this study I try to close this research gap by analyzing the victim-offender mediation in China's Tibet, where influenced by religion, history and culture, a set of local solutions to control criminal offenses have traditionally been formed. Based on the field survey and second-hand information, I discuss how religious factors play a role in local victim-offender mediation in terms of the basis for mediation, mediator, mediation tactics, and guarantee for mediation agreement. While Buddhism acts as a form of self-control over the adherents of Buddhism, it works as a form of social control as well. Buddhist lama as the main mediator strategically uses Buddhist principles as mediation tactics in victim-offender mediation. After the mediation agreement is reached, religious ceremony is usually conducted as a guarantee. In conclusion I summarize the possible contribution of the research findings to the basic issues of restorative justice.
\end{abstract}

Keywords: victim-offender mediation; restorative justice; Buddhism; crime; Tibet

Citation: Feng, Lu. 2021. How Buddhism Plays a Role through Victim-Offender Mediation in Handling the Challenges of Crime in China's Tibet. Religions 12: 699. https://doi.org/10.3390/rel12090699

Academic Editor: Lee Ross

Received: 3 August 2021

Accepted: 26 August 2021

Published: 30 August 2021

Publisher's Note: MDPI stays neutral with regard to jurisdictional claims in published maps and institutional affiliations.

Copyright: (C) 2021 by the author. Licensee MDPI, Basel, Switzerland. This article is an open access article distributed under the terms and conditions of the Creative Commons Attribution (CC BY) license (https:// creativecommons.org/licenses/by/ $4.0 /)$.

\section{Introduction}

Religion plays a significant role in the way Western societies respond to criminal offenses. Many researchers from various social science backgrounds hold that religion can reduce crime and delinquency by increasing self-control and social control (Hirschi and Stark 1969; Ross 1994, 1996; Ellison and George 1994; Johnson et al. 2001; Clear and Sumter 2002; Adamczyk et al. 2017). The landmark study named "Hellfire and Delinquency" by Hirschi and Stark reported no relationship between adolescent religiosity and delinquency (Hirschi and Stark 1969). However, the majority of studies have tended to confirm significant negative associations between religion and crime. In addition to the understanding of relationship between religion and antisocial behavior, research in the relatively new subfield of positive criminology was focused on the relationship of religion and prosocial behavior (Batson 2012, p. 12). This line of research expanded beginning in the 1980s to include studies of religion and religion-based rehabilitation programs in prisons and other correctional contexts (Angela 2010; Johnson 2012; Kerley 2014; Jang et al. 2018). It indicates that restorative approaches tend to be more effective than traditional and punitive approaches (Ronel and Elisha 2011; Ronel and Segev 2015).

Restorative justice has been found applicable at different stages within the criminal justice system. Positive criminology focuses on the role of religion playing at the backend of the system with offenders already serving prison sentences, such as religion and religion-based rehabilitation programs in prisons such as Offender-led Religious Movements (ORMs) (Morag and Teman 2018; Johnson 2021). In addition, scholars have paid attention to religion and restorative justice at the previous stage, that is, the stage of determining the offender's responsibility. In general, the values inherent in restorative justice have a spiritual and/or religious basis (Gumz and Grant 2009). Many scholars described how religion served as the spiritual roots of restorative justice in major world regions such as Christianity, Islam, Buddhism, Judaism, Hinduism, and Sikhism (Hadley 2001; 
Weitekamp and Kerner 2002; Zehr and Toews 2004; Sarre and Janette 2011). Some scholars talked specifically about the role of religious bodies in furthering the practice of restorative justice since the Mennonites supported victim-offender mediation program in the United States and Canada in 1970s (Zehr 2002; Misleh and Hanneman 2003; Hascall 2011; Jones and Sims 2016). Further, the practice of restorative justice has been extended to the reconciliation of serious criminal offenses caused by civil wars in some African countries such as South Africa, Sierra Leone, and Libeya, which is regarded as a combination of political reconciliation between groups and individual reconciliation between victims and offenders in those groups (Kohen 2009; Graybill 2017; Shin 2020). Although an amalgam of religion and restorative justice is attractive to many researchers and practitioners, Gedicks and Greenwood questioned whether religious values and bodies could be relevant to restorative justice in the secular criminal justice system based on the ideal of "separation of church and state" (Gedicks 2003; Greenwood 2003).

While many scholars have conducted extensive research on religion and crime according to their different research interests and along various theoretical paths in recent decades, there are still some drawbacks in this field. First, there is little in the field that focuses on non-Western religions. Since the late 1800s, definitions of religion have been grounded in Western and Judeo-Christian conceptual frameworks (Sumter et al. 2018). The study of religion-crime relationship among adherents of non-Western religions has been neglected so far (Junger and Polder 1993; Ellis 2002; Ahmed 2009). Second, there has been little research available on the relationship between Buddhism and restorative justice despite the obvious commonality of forgiveness in different religions as spiritual roots of restorative justice. Research is needed that answers the less-often addressed question of non-Western religions' role in the practice of restorative justice. Third, as pointed out by Ulmer and Harris (2013), within sociological and criminological scholarship, compared to a number of literatures on religion-crime relationship at the micro-level with empirical results, less attention was given to how religion impacts crime in an area or place at the macro-level.

Thus, this paper responds to the lack of research on how religion plays a role in restorative justice and decreases the side effect of crime in non-Western countries at the meso-level. To clarify how Buddhism plays a role through restorative approaches in handling the challenges of crime in China's Tibet, the paper is organized as follows. After the introduction, Section 2 describes why Tibet is a vivid example to observing religion and crime, and religion and restorative justice relationship in non-Western countries. In Section 3, the general process of Tibetan restorative justice practice namely victim-offender mediation to handle criminal offense is described based on both first-hand and second-hand information. Sections 4-7 discuss how religious factors play a role in local victim-offender mediation in terms of the basis for mediation, mediator, mediation tactics and guarantee for mediation agreement. Section 8 summarizes the paper's possible contribution to existing literature and draws wider implications for further study.

\section{Victim-Offender Mediation in China's Tibet: A Vivid Example of Observing Religion and Restorative Justice Relationship}

Most Tibetan men, especially the pastoral nomads, prominently carry knives and often talk about violence in their daily conversations. There used to be a high incidence of crimes of violence among the Tibetans (Ekvall 1954; Pirie 2013). According to the Tibetan primal rule of retaliation, if someone is killed, it will lead to an endless chain of reprisal and counter-reprisal. Law enforcement in Tibet is weakened by the factor of distance from the administrative and judicial organs. Finding and maintaining contact with the elusive nomads in a criminal case was too difficult to make law enforcement effective (Ekvall 1964). In order to maintain the peaceful social order for the society's interest of its own survival, Tibet has local customs to control anti-social behavior, which is called life indemnity. It refers to a fine or payment with special reference to indemnity paid to the family of a man who has been killed (Ekvall 1954). 
As noted by Ross (2021), in the criminal legal system, punishments should create direct results and benefits for all parties involved: the offender, the victim, and society in general. However, the state's criminal justice system focuses on punishing the offender, failing to restore the relationship between the offender and victim damaged by the crime, and provide sufficient compensation to the victim. The official legal response cannot resolve the feud between the parties and is likely to cause reprisal and counter-reprisal in accordance with Tibetan primitive rule of retaliation, resulting in more loss of lives and social instability. Such cases were found in Pirie (2013) and my field surveys. Therefore, not only are the parties willing to mediate based on Tibetan customs of life indemnity as a preferred remedy, but local government officials have also acquiesced to the existence of mediation. ${ }^{1}$ The procedure of mediation under the custom of life indemnity to resolve the feud caused by a violent crime, is very much analogous to the concept of victim-offender mediation. Victim-offender mediation, as a typical form of "restorative justice", refers that with the help of the mediator, the victim and the offender directly communicate and negotiate to resolve the criminal offense (Van Ness 2005). It aims to make up for the harm suffered by the victim and restore the social relationship destroyed by the crime. Local victim-offender mediation in Tibet also seeks to develop active responsibility on the offender who has grown accustomed to a lifestyle of irresponsibility (Braithwaite 2009, pp. 497-506).

As far as the origin of Tibetan victim-offender mediation under the custom of life indemnity is concerned, little is known of its origin (Ekvall 1954). However, the introduction of Buddhism during the Tubo Dynasty ruled by Songtsan Gampo had an important impact on the custom (Muchi 2013). During this period, Buddhism became the dominant religious belief in Tibet. Most Tibetans currently keep religious allegiance. Buddhism, as the traditional authoritative force in Tibetan society, not only penetrates into the customs, holidays, and taboos of Tibetans, but also gets involved in dealing with the challenges of crime. Specifically, prohibiting killing is the most important principle of Buddhism and buying life is a means of obtaining merit throughout the Buddhist world. ${ }^{2}$ Therefore, Buddhism has played an important role in substituting blood revenge with compensation (Ekvall 1954; Zhang 2002, p. 281; Suonan 2004, p. 30; Cai 2007, p. 162). Therefore, how Buddhism plays a role through restorative approach in dealing with the challenges of crime in China's Tibet is a vivid example to observe the relationship between religion and crime in non-western countries.

To understand the practice of victim-offender mediation in Tibet, I conducted a field survey in an agricultural village in Chamdo, Tibet, China from December 2020 to April 2021. ${ }^{3}$ The village has full access to electricity and internet. It is closer to the administrative and judicial organs than the remote pastoral area. I conducted a series of semi-structured interviews among Lamas, ${ }^{4}$ villagers, judges, and government officials about how victimoffender mediation operated and how religious factors played a role in victim-offender mediation (Appendix A). ${ }^{5}$ It should be noted that because it was a small sample size survey, the generality of research findings is limited. In order to enhance the generality of my research findings, in addition to first-hand information, I collected and analyzed secondhand information pertinent to victim-offender mediation reported by other international and Chinese scholars in other regions of Tibet and Tibetan areas. Although the practice of victim-offender mediation in Tibet has undergone changes since the establishment of the custom of life indemnity, it still substantially follows the similar pattern of mediation as previously. In addition, although there are significant local variations in Tibet and other Tibetan areas of China, ${ }^{6}$ the general picture of victim-offender mediation I describe in the following sections shares many commonalties based on Ekvall's (1954) and Pirie's (2013) surveys on the grasslands, and my survey in an agricultural village. Additionally, I explain the differences of research findings of victim-offender mediation between other scholars and $I$ in the paper. 


\section{General Process of Victim-Offender Mediation in China's Tibet}

Case 1 shows the cause and mediation process of an ordinary criminal offense in Chamdo, Tibet. According to the field surveys conducted by me and other scholars (Ekvall 1964; 1968, pp. 76-79; Pirie 2005; Chen 2008, pp. 290-98; Zhou 2015, pp. 92-94), local victim-offender mediation is usually carried out in this way. After a criminal offense happens among Tibetans, firstly, with the consent of the parties or their family members (in the case of the victim's death), the parties and their family members as well as the entrusted persons of the parties shall jointly negotiate. ${ }^{7}$ If they agree to mediation, on the one hand, they will choose someone trusted by the parties as the mediator. On the other hand, the offender will pay a certain amount of "good faith fee" to the victim according to the severity degree of the crime, which will be kept by the mediator; or, if the fee is unaffordable, the offender should present a letter of guarantee and find a guarantor. ${ }^{8}$

Secondly, the parties or the entrusted persons go to the selected mediator and request the mediator to preside over the mediation. Locally respected elders, prestigious tribal leaders, and religious figures are usually chosen as mediators. ${ }^{9}$ If the mediator agrees to the request, the specific time, place, and list of participants will be determined as soon as possible. The mediator then begins to investigate and mediate the criminal offense, during which the parties and their family members state the course of the criminal offense and provide evidence. Most importantly, the victim proposes the amount of compensation and negotiates with the offender. The mediator, based on the investigation and the opinions of the parties especially the opinions on the amount of compensation, combined with the victim's cause of death or injury, identity, and other factors, as well as local customary compensation rules, specifies the compensation amount including both real and symbolic value. The custom of life indemnity is used to handle not only serious offenses resulting in death, but also lesser offenses such as theft and injury. The content and amount of compensation varies according to the severity of the crime. The mediator has no power to impose a solution upon the parties but only bring the parties to reach an agreement proposed by the mediator.

Finally, the offender pays the compensation to the victim within the time limit specified in the agreement. ${ }^{10}$ Compensation is generally paid in cash, and when the cash is insufficient, it is paid at a discount in the form of livestock or other materials. In addition to the obligation of monetary compensation, the agreement usually also includes the guarantee of remaining at peace, a ceremony of Hada exchange, and obligation of the offender to plead guilty and apologize to the victim. Because the mediation process often involves many participants from the victim's and the offender's family, it is easily known to the whole community. In this regard, apology is conducive to promoting solidarity of community. At this point, a complete victim-offender mediation process is over. What needs to be explained is that although I summarize the general steps of mediation process, it does not mean that the mediation process in practice strictly follows the order of these steps, while it is rather flexible. Besides, the mediation in practice cannot always be successful at once. If the mediation fails, another mediator will most likely be invited to continue until an agreement is reached, which may last a long time.

Case 1: This case happened in the village I surveyed, and the lama who participated in mediation told me about it. The cause of the case was that two trucks belonging to villager $A$ and villager $B$ of the Village were parked side by side. A's truck accidentally collided with B's truck. B required extremely high compensation. A refused to pay and quarreled with B. Fortunately, someone persuaded the parties not to fight at that time. Then, the parties agreed to meet and fight later. Soon, the parties met in an alley. B took his son and daughter. The parties engaged in hand-to-hand combat. A couldn't beat the three of Family B, so he took out the knife he carried and stabbed B. B was afraid that A would hurt his son and daughter, so he pleaded. Seeing that their father was injured, B's son and daughter rushed to A and tried to grab the knife. B's son grabbed the knife 
in A's hand, and A directly drew the knife from his hand, causing serious injury to B's son.

After the case happened, the relatives of the parties were worried and went to the temple in the village and asked the lamas for mediation. Because there were some male members of Family B, if the parties could not eliminate their hatreds, these male members of Family B would most likely seek revenge from Family A. It was likely that more members of the two families would lose their lives. Because the two families usually went to the temple to pray, the reincarnate lama and other senior lamas agreed to mediate this case. Three or four members from Family A and Family B participated in the mediation, respectively. The course of the case was not complicated, and the controversial point between the parties focused on the specific amount of compensation. Family B proposed a compensation amount of RMB 200,000. Family A was unwilling to pay. They insisted that if B had not proposed a ridiculously high compensation for a minor truck collision loss, it would not cause subsequent injury. After several rounds of bargaining, they reached an agreement that A paid RMB 80,000 to B as compensation with the help of the reincarnate lama and other senior lamas. After the mediation agreement was reached, the parties were asked to make prostrations for three times before the reincarnate lama. Then they abided by the agreement and have so far remained at peace.

In essence, this is a mediation process towards problem-solving and harmony (Bush and Folger 1994, pp. 236-59). There is no substantial difference between victim-offender mediation and other kinds of folk mediation except the basis. Generally, the basis of folk mediation is folk norms, while that of Tibetan victim-offender mediation is the custom of life indemnity affected by the factors of Buddhism. A handbook of restorative justice by the United Nations acknowledged that restorative justice was comparable to the good old system of resolving dispute by village elders (United Nations Office on Drugs and Crime 2006). Specifically, Tibetan victim-offender mediation has distinguishing features as follows.

First, the whole process is consensual. According to Tanase's consensus theory, as a dispute resolution institution, reaching a consensus is the basic condition for its functioning at two stages of dispute resolution: the initial stage and final resolution stage (Tanase 2004, p. 79). Only getting the consensus of both parties, can religious figures participate in mediation and can the agreement be implemented. In addition, religious figures focus on promoting the parties to achieving consensus instead of making judgment. As noted by Tanase (2004, p. 79), there is little "mandatory consensus" in local victim-offender mediation.

Second, the mediation process is flexible. Tanase believed whether the mediator has sufficient coercive power influences the flexibility of mediation process (Tanase 2004, pp. 39-40). If the coercive power of the mediator is not enough to maintain the implementation of the agreement, the process will most likely be flexible. Religious figures as mediators have little secular power to coercively enforce the agreement. Thus, they primarily consider the willingness of the parties and flexibly propose a scheme in accordance with local norms and values as well as traditional notions of justice, in order to guarantee successful implementation of the agreement. A similar situation also exists in some countries. For instance, Katarungang Pambarangay rules in The Philippines directed resolving the conflict without regard to technical rules of evidence (Silliman 1985). The indigenous conflict resolution mechanisms in Nigeria relied on cultural norms, values, and communal moral conscience rather than legal or political codes or laws (Murithi and Ives 2007).

\section{Buddhism as the Basis for Victim-Offender Mediation}

In case of criminal offense, why are the Tibetan victim and the offender willing to resolve the feud by means of mediation and compensation? This question involves the basis 
for victim-offender mediation, which is closely relevant to Tibetan Buddhism (Lamaism). Buddhism exerts not only self-control over the adherents of Buddhism, but also social control over members of Tibetan society, to establish the basis for the willingness of the offender and the victim to mediate.

\subsection{Buddhist Principles as a Self-Control Mechanism}

As pointed out by Ross (2021), regardless of religious denomination, there is a doctrine of forgiveness and restoration. From many passages of Christian scriptures, one can recapture the heartbeat of God for restoration, reconciliation, and peace (Allard and Northey 2001, pp. 119-41). The religious law of Islam, which is based on Islamic teachings, also includes forgiveness and compensation (Absar 2020). The Jewish sages understand atonement as the effect of divine forgiveness (Segal 2001, p. 185). The principles of Buddhism serve as the basis for victim-offender mediation between Tibetans who believe in Buddhism, which is reflected in three aspects. Firstly, the soul is immortal and there is a circle of life. According to the eternal cycle of birth and death in Buddhism, a person has a soul, and death means the beginning of another cycle of life and another re-birth of a person. The individual endorsement of life after death is regarded as an important domain of religiosity (Reisig et al. 2012). With an immortal soul, the victim can be reborn after death. Since the victim can be reincarnated, so can the offender. Therefore, even the death penalty is not the most severe punishment. It would be better to make the offender pay monetary compensation; part of the compensation is paid to a reincarnate lama or a senior lama who is requested to recite scriptures to release the soul of the dead and guide the victim's soul to be reincarnated smoothly as soon as possible. This is the greatest blessing for the victim.

Secondly, killing is the biggest evil, and not killing is the greatest good deed. The five precepts and 10 good virtues of Buddhism are the most important precepts and codes of conduct for Buddhists. ${ }^{11}$ The adherents of Buddhism generally adhere to the idea that: since killing is the biggest evil, depriving the offender's life is also a violation of the first precept of the "five precepts", which makes the victim commit an evil act. The Tibetan custom of life indemnity is not just the action of "paying money to buy the victim's life", which only emphasizes monetary compensation and does not respect life, but precisely the performance of respecting life and the first of the 10 good virtues. There seems to be an obvious contradiction here: Tibetans are generally adherents of Buddhism and should abide by the basic ethic of Buddhism-the revulsion against taking of life. Then why is there a high incidence of violent crimes in Tibet, and even the chain of reprisal and counter-reprisal between two families is endless? I asked this question of several villagers who are devout Buddhism believers while also accepting the rule of revenge. They said "Blood debts pay for blood" is a handed-down method of rights protection that Tibetans have long been accustomed to; they seemed to be confused about the relationship between the rule of revenge and reconciliation and thought the two were different things. Further, the lamas I interviewed explained in this way that the core of Buddhism is to change the human nature, retain the inherent good and remove the inherent evil. Therefore, the focus is to persuade the parties to resolve the feud in a peaceful way with the ethics of Buddhism after a killing case occurs. In fact, no killing is the first commandment of a Buddhist lama, not an adherent of Buddhism. Similarly, case studies of African traditional restorative justice also found that there was a continuum ranging between the opposite poles of retaliation and reconciliation (Wilson 2001; Huyse and Salter 2008, p. 5).

Thirdly, there are the ideas of "Karma" and "Six Paths of Re-birth". ${ }^{12}$ The offender's soul will be subjected to the severest religious punishment (that is, the karma) after death, and will inevitably fall into hell, which is the lowest and most painful path among the Six Paths of Re-birth. Hell is real for Tibetans who believe in Buddhism. They are more afraid of their souls falling into hell and suffering than being deprived of liberty or even life. Considering the pain the offender will suffer after death, it is unreasonable to deprive the offender's life. On the contrary, if they keep the life of the offender and let the offender 
repent and do good deeds for the benefit of all beings, the offender may jump out of the Six Paths of Re-birth and eliminate the evil karma.

\subsection{Buddhism as a Social Control Mechanism}

There is a complex relationship between victim-offender mediation and Buddhism, which cannot be simply attributed to Buddhist principles as a self-control device over Tibetans. For instance, Pirie (2006) found that, the people in a Ladakhi community were strong adherents of Tibetan Buddhism and had unequivocally accepted the idea of karma; however, they did not regard their religion as a source of moral guidance. However, even if the norms of compassion and Buddhist morality, as well as concerns about rebirth only play a limited role in guiding the victim and the offender to mediate, it cannot be denied that its influence in another dimension, namely, the social control of religion.

Durkheim (1951, pp. 152-70) stated that religion is a crucial and integrative mechanism for fostering a set of common values and beliefs and maintaining social order from the perspective of functionalism. Buddhism reinforces the rules in Tibetan society through teaching the same set of values, beliefs, and norms for Tibetans who believe in Buddhism, thus promoting solidarity of Tibetan society. Specifically, compared with revenge, life indemnity through victim-offender mediation has obvious social benefits and enhanced the stability of Tibetan society. Once this alternative was accepted, it would in turn strengthen the authority by which it was introduced and redound to the credit of the lamaist leaders (Ekvall 1954). At the same time, Durkheim and Marx held that religious beliefs control individuals to the extent that religious beliefs are internalized and used by members of society in their daily lives (Ritzer and Stepnisky 2017, pp. 76-111). The adherents of Buddhism are willing to mediate rather than avenge after a criminal offense happens, it is because the Buddhist beliefs that killing is immoral and seeking peace have been internalized by them to some extent. Ekvall's (1964) survey indicated that Tibetan men were unwilling to prolong the conflict because they longed for time to engage in religious activities. Through this process, religion acts as a form of social control.

In addition, religion as a form of social control, controls the behavior of its members as embodied in meeting the expectations of the group and maintaining contact with the group (Sumter et al. 2018). I once asked the lama who was the mediator in case 1, why he agreed to act as the mediator, and he replied: "Our temple is responsible for maintaining the order of the village." Ekvall's (1964) earlier research mentioned that the lamas in an area of Tibet were unhappy due to the decrease of people who came on pilgrimage and brought wealth to their temples due to local constant vendettas. In this sense, failing to adhere to dispute resolution norms becomes a violation of the Buddhist group's expectation, and the Buddhist community will try to exert influence over the decision and behavior Tibetans engage in.

\section{Buddhist Lama as the Main Mediator in Victim-Offender Mediation}

Folk mediation in local and community-based processes, usually involves a leader of traditional leadership structures. In Somaliland, people relied upon their traditional clan elders as "the repositories of moral authority and catalysts for societal harmony with regards to dispute resolution" (Murithi and Ives 2007). In Yemen, mediators were usually men-maybe a tribal leader or anyone with a good reputation (Adra 2011). Mediators in Tibetan victim-offender mediation include highly respected elders, prestigious tribal leaders, and religious figures. Considering Buddhism as the basis for victim-offender mediation, it is not surprising that the most preferred of all mediators are high-stature religious figures. They were presumably immune to partisanship and mean motives and have high status and command (Ekvall 1964; Pirie 2013), thus they were able to restore good relations.

In particular, the highest lamas as charismatic authorities were invited to preside over the mediation when the elders and leaders failed to get the victim and the offender to reach an agreement (Ekvall 1968, pp. 78-79; An 2017). The highest reincarnates are seen as 
being able to resolve the most problematic conflict. The villagers I interviewed said they would always tell the truth in front of the reincarnate lama in their village. Pirie described a charismatic reincarnate who had rejuvenated the local monastery and commanded great respect among the local population and easily resolved the outbreak of a violent attack (Pirie 2013).

The authority of religious figures in victim-offender mediation is not only higher than other mediators of prestige and power, but also higher than the state's administrative and judicial organs. Yeh investigated a conflict caused by matsutake mushrooms harvesting among Tibetans in Diqing, Yunnan Province, China found that there was no local respected religious figure as a dispute resolver; so, the parties had to take the dispute to court, but were not satisfied with the court's judgment and each accused the other of nepotism with the court. She even made the conclusion that in some Tibetan areas, serious grassland conflicts or serious issues of grazing rights could only be effectively resolved with the intervention of high-stature religious figures rather than government officials (Yeh 2000). The Tibetans in my surveyed village also told me 'The police station is not welcome here, and we all reject it".

In sum, as the main mediator, the Buddhist lama plays an important role in victimoffender mediation. However, it needs to be pointed out again that even if a Buddhist lama has high authority, his power is persuasive rather than coercive; while the mediation presided by the lama is not invariably successful (and this is confirmed by Ekvall 1964 and Pirie 2013).

\section{Strategical Use of Buddhist Principles as Mediation Tactics}

As for the mediation tactics, Pirie argued that Buddhist lamas did not refer to Buddhist principles or morality during the mediation process (Pirie 2005). This is a rather different picture from that presented by some scholars and me (Ekvall 1954; Chen 2008, pp. 292-93; Zhou 2015, pp. 92-94). Religious figures have accumulated a set of methods and strategies for resolving disputes, not only based on religious teachings, but that also include history, precedents, and tradition. When religious figures preside over the mediation, they are good at strategically using Buddhist principles to make the victim and the offender reach an agreement.

“They brought to the mediation process the higher considerations of religious values-the transcendent ethics of Buddhism-and they spoke with unction of the displeasure of supernatural beings, of the implications of karma, of the desirability of virtue, of the heinousness of the sin of taking life, and of the pains of hell. They appealed to the deepest beliefs of the Tibetan world view." (Ekvall 1964)

The success of a dispute resolution service pilot designed to meet the needs of local people in New South Wales indicated that mediation should be flexible enough to adapt to community preferences on a case-by-case basis (Cunneen et al. 2005). In the conversations I conducted with a Lama in the village, he told me that he used Buddhist principles to persuade the parties according to specific circumstances of the criminal offense. If the crime was caused by historical reasons, for example, caused by grassland dispute which is often due to the dissatisfaction with the distribution of grazing rights, Buddhist principles were not very useful, and he would go back into history and similar precedents. If the crime was caused by a quarrel or fight, he would cite the preachments of Buddhism or told Buddhist stories. "Killing requires atonement. If you (the offender) can get forgiveness from the victim and make the victim feel better, you can atone for your sins to some extent. At this time, Buddhist principles play a role. It would be easier for making the parties reach an agreement." The lama said. As showed in Case 2, the reincarnate lama gave a legendary explanation of the relationship between the offender and the victim in their previous and present lives and convinced the parties by properly applying the idea of karma.

Case 2: There was a lamasery of the Jonang sect in Rangtang County at the junction of, Sichuan Province and Qinghai Province, China. Two Tibetan herdsman 
families, A and B, resided at the grassland near the lamasery. Family A lost a cattle-yak during grazing, and suspected that it was stolen by the eldest son of Family B. Then the two families often quarreled. Once during a quarrel, the eldest son of Family B picked up a stone from the ground to throw it at the second daughter of Family A, resulting in her death. Family B asked the reincarnate lama of the lamasery to mediate. During the mediation, the reincarnate lama told the parties about the eternal cycle of birth and death and the idea of karma, and, with the supernatural power, told the parents of the parties: "In the previous life, the eldest son of Family B was a cat, the second daughter of Family A was a mouse, and the predecessor of the cattle-yak was a dog. As the dog came out to chase the cat, the cat could not eat the mouse and starved to death. This is the cause. In this life, the eldest son of Family B killed the second daughter of Family A by mistake, which was the effect". Finally, Family B agreed to pay RMB 16,000 to Family A as compensation, and Family A promised not to report the case to government officials again. Later, other herdsmen asked about the second daughter of Family A, and A said that the second daughter was tripped over a stone while driving the cattle and killed by the stone, and bemoaned the "bad luck". After that, the herdsmen near the lamasery forgot this matter, as if the second daughter of A family did not exist. (Chen 2008, pp. 292-93)

\section{Religious Ceremony as the Guarantee for Mediation Agreement}

Whether a mediation agreement is reached with the help of a Buddhist lama or not, it is often followed by a ceremony to make the agreement more binding. As noted by (Ekvall 1954), after the compensation was completed, both parties would take an oath in the presence of mediators, to assure that the case would not be used as an excuse for arguing no matter what happened later. Sometimes the parties would also exchange Hada to show kindness for each other (Fang 2017). Since Tibetans keep allegiance of Buddhism, the ceremony as a guarantee for mediation agreement is usually with religious factors.

In the village I surveyed, the mediator usually brought disputing parties to the statue of Buddha or the reincarnate lama of the temple and made them vow that they would abide by the agreement and would not revenge. Taking Case 1 as an example, after the mediation agreement was reached, the parties were asked to make prostrations for three times before the reincarnate lama of the temple, which was a vow to express never reneging on the agreement, otherwise it would be a betrayal of the reincarnate lama. The temple then gave each of the parties a Buddha statue as a condolence to the two families' misfortune. In some Tibetan areas, after the agreement was reached the lama of the local temple would sign a paper agreement, which would be held by the temple, the representatives of the parties, and the mediator (if the mediator was not from the temple) (Zhou 2015, p. 94).

In addition to the constraints by the supernatural sanctions involved in swearing, the ceremony also embodies the elements of repentance and forgiveness that are consistent with restorative justice. In the practice of Tibetan victim-offender mediation, apology is not only a formality to facilitate the mediation process, but also an integral part to the restorative justice process. Dignity is very important to Tibetans. In the surveyed village, I collected several cases that because there were no apologies for minor misconducts, the minor disputes turned into serious injury or killing cases. Therefore, if the party does not apologize for the act that damages the dignity of the other party during mediation, it will be difficult to reach an agreement. In addition, apology is also an integral part of the agreement. The offender was requested to apologize to the victim, and apologies may be made by offering religious books (Pirie 2005; Pirie 2008, pp. 217-40). The result of victim-offender mediation is guaranteed through the performance of a ceremony with religious factors, which not only enhances the execution of the agreement but also improves the satisfaction degree of the parties. For instance, studies of victim-offender mediation practice in Sierra Leone indicated that a ceremony of repentance and forgiveness may be even more important to reconciliation than truth in the end. Even victims did not hear 
actual confessions of offenders, they were still struck by the evidence of remorse in the ceremony (Kelsall 2005; Graybill 2017, p. 4).

\section{Conclusions}

Although the result of victim-offender mediation is mainly in the form of monetary compensation, it cannot be simply understood as paying money to solve the side effects of crime or paying money instead of punishment. From the perspectives of the basis for mediation, mediator, mediation tactics, and guarantee for mediation agreement, the victim-offender mediation in China's Tibet reflects that the offender is required to atone for his/her act by the power of Buddhism. Thereby, the religion-based restorative approach to handle criminal offense is helpful to develop non-criminal identity change which is going beyond the religion's constraining function (Jang and Johnson 2017, pp. 74-86), and further restoring social equilibrium. At the same time, as noted by Galanter (1981), the folk norm does not always mean harmony and equality. It often reflects narrow considerations. Therefore, it cannot be ignored the potential side effects of local victim-offender mediation on overall social order maintained by the state's criminal justice system.

The paper describes and analyzes how Buddhism plays a role in decreasing the side effect of crime through victim-offender mediation in non-Western countries, contributing to the understanding of religion and restorative justice beyond Western countries. On the one hand, Howard Zehr, who is regarded as the grandfather of restorative justice movement, initially popularized the dichotomy of restoration and retribution between restorative justice and traditional justice (Zehr 1990). Nevertheless, Brunk warned that both retribution and restoration reflect a central and moral intuition that something is owed to the victim and society by the offender and that there ought to be a reciprocity between offence and response, so they are not the opposites (Brunk 2001, pp. 31-56). In response to this basic issue of restorative justice theory, the paper provides evidence of the coexistence of retribution and restoration in Tibetan practice of handling criminal offense. On the other hand, restorative justice is primarily a needs-oriented rather than a deserts-oriented approach to justice (Sullivan and Tifft 2001). However, victim roles and issues were omitted in the checking list of restorative elements in some research on restorative justice. This paper pays attention to this omission and gives concerns about the victim's material and spiritual needs during the whole process of victim-offender mediation in Tibet.

Since the reform and opening up of China, although the system of administrative appointments and political accountability remains centralized (Liu and Tao 2007, pp. 166-89), the state has changed its governance strategy and relied on technical governance to a certain extent. Yeh (2003) and I both found that religious figures, especially the influential religious figures, have been gradually included in the state's organs or semi-state's organs as dispute resolvers. These changes also affect the religion-based victim-criminal mediation in Tibet. "Lawmakers who are unappreciative of the social conditions that foster informal cooperation are likely to create a world in which there is both more law and less order" (Ellickson 2003, p. 354). A vice president of the county-level court told me that state law should effectively coordinate with Tibetan folk norm to improve the acceptance of the criminal case-handling result and maintain social order. "Let the parties feel justice. "He summarized. The further study can thereby focus on how the state's restorative justice program integrates local mechanism. It can also be discussed the conflict and adjustment between government interference and folk mediation, as well as the complex and dynamic relationship of state's authority and traditional authority from a broader perspective (Scott 1997).

Funding: This research was funded by National Office for Philosophy and Social Sciences of China, grant number 17CFX017.

Acknowledgments: The author thanks Luosong Keqiu for his assistance in the field survey. The author also appreciates three anonymous reviewers and the academic editor for their constructive critiques on improving the manuscript. 
Conflicts of Interest: The author declares no conflict of interest.

\section{Appendix A}

\section{For Lamas:}

Outline of the semi-structured interviews (Excerpts)

1. How many disputes have you mediated as a mediator so far? How many disputes do you mediate on average per year? How many criminal offenses have you mediated? How many criminal offenses do you mediate on average per year?

2. What kinds of criminal offenses have you mediated?

3. How do you mediate a criminal offense generally?

4. Can you recall an impressive criminal case you mediated and introduce the whole process?

5. Based on your experience, what role do you think Buddhism plays in handling criminal offenses?

(1) Do you think Buddhism teachings can reduce the occurrence of crime? Why?

(2) After a criminal offense occurs, what role do you think Buddhism plays in handling the problems caused by the offense?

For other mediators, except for Lamas:

1. How many disputes have you mediated as a mediator so far? How many disputes do you mediate on average per year? How many criminal offenses have you mediated? How many criminal offenses do you mediate on average per year?

2. What kinds of criminal offenses have you mediated?

3. How do you mediate a criminal offense generally?

4. Can you recall an impressive criminal case you mediated and introduce the whole process?

5. Based on your experience of presiding over mediation, do you think there are some differences of presiding over mediation between you and lamas? What are the differences? And why?

\section{For villagers:}

1. Do you believe in Buddhism?

2. What are your usual religious activities?

3. In what ways do you think your religious belief and religious activities have affected you?

4. How do you think of Tibetan rules of revenge after a criminal offense happens?

5. Do you think Buddhism is helpful to resolve disputes especially criminal offenses? In what ways is it helpful?

6. Has any criminal offense occurred in your family?

(1) If it happened, how did you or your family handle it?

(2) If not, what would you do if it happened?

\section{For judges at county-level:}

1. Are all the criminal offenses in your county resolved through the court? If not, what is the proportion of criminal offenses that are not resolved through the court according to your estimation? Has this proportion changed during recent years? And why?

2. Do you know how a criminal offense is handled if it is not resolved through the court?

3. How do you think of the phenomenon that criminal cases fail to be handled through formal trial? Why does this phenomenon occur?

4. How do you think of the role of life indemnity norm in handling criminal offenses?

5. Have you ever encountered a criminal case that went through not only court's judgement but also victim-offender meditation? Can you recall and introduce such a case that impressed you deeply?

6. Do you think there is a conflict between the state's criminal justice system and local mediation rules? If so, how do they conflict? How do you think the conflict should be adjusted? 


\section{For governmental officials at village- and county-level:}

1. What kinds of disputes and criminal offenses often happen in the village/ county?

2. Do you know how the criminal offenses are handled?

3. How do you think of the role of life indemnity norm in handling criminal offenses?

4. What role does the temple or Lama play in handling criminal offenses?

5. Does your department have any contact with local temples or Lamas? What kind of contact?

\section{Notes}

1 It is necessary to explain that the local offender is subject to two systems, whereby the offender may have to suffer double punishment, both imprisonment and even more serious punishment according to the state's criminal justice system and compensation through traditional victim-offender mediation. Apparently, there conflict exists within the dual system. However, this paper is not focused on the conflict, as well as the complex and dynamic relationship between the state's authority and local society's tradition.

2 For instance, Buddhist devotees buy fowl and animals from the butchers to keep them alive. This is a deed of buying life.

3 The village has a rural agricultural population of 1281 and no population of animal husbandry. The main plants are highland barley, wheat, turnip, and rape.

4 Lama is a title for a teacher of the Dharma in Tibetan Buddhism. See https://en.wikipedia.org/wiki/Lama (accessed on 18 August 2021).

5 The interviewees are: three Lamas from the temples, two villagers who presided over mediation, eight villagers (not including the villagers I had daily conversations), two judges, and a vice president of the county-level court, a village secretary of the Village Committee, and an official working in the county-level government.

6 Tibetans mainly lived in three Tibetan areas in Chinese history: U-Tsang, Amdo, and Kham, which are divided into Tibet and 10 Tibetan areas in provinces of Sichuan, Yunnan, Gansu and Qinghai.

7 In the paper the victim refers to both the victim self and the victim's family members and close relatives. In case of the victim's death, his/her family members or close relatives will participate in the mediation. Similarly, the offender is not limited to the offender self, but also includes his/her family members and close relatives.

8 It needs to be explained that there are local variations in terms of the guarantee step. Zhou's investigation in the Ganzi Tibetan area of Sichuan Province in China found that found the guarantee step is conducted before mediation (Zhou 2015, p. 93), while some scholars and I did not find this step in some regions of Tibet (Ekvall 1964; Pirie 2013).

9 Here the identification of mediators is based on both my survey and second-hand information. In the agricultural village I surveyed, religious figures and elders are mediators. While on the grasslands tribal leaders presides over the mediation according to the surveys by Ekvall $(1954,1964)$ and Pirie $(2005,2013)$.

10 In practice, breaking a settlement is mainly manifested as the offender's failure to compensate. Then, the victim is likely to either seek self-relief such as reprisal, or inform the police station or state's judicial organs.

11 Cited from Ekottara Agama (增壹阿含经), available at: https://www.guang5.com/fojing/ahanjing/34283.html; and Buddhabhasita Dasabhadra Karmamarga Sutra (十善业道经), available at: http:/ / www.jingangjing.com/shishanyejing.htm (accessed on 28 April 2021).

12 Cited from Lam Rim Chenmo (菩提道次第广论), available at: http:/ / www.xianmifw.com/treasure/book.php?id=6 (accessed on 28 April 2021); and Great Treatise on the Perfection of Wisdom (大智度论), available at: http://www.lianhua33.com/dj.htm (accessed on 28 April 2021).

\section{References}

Absar, Aftab Absar. 2020. Restorative justice in Islam with special reference to the concept of Diyya. Journal of Victimology and Victim Justice 3: 38-56. [CrossRef]

Adra, Najwa. 2011. Tribal Mediation in Yemen and its Implications to Development. AAS Working Papers in Social Anthropology. Available online: http:/ / epub.oeaw.ac.at/0xc1aa500e_0x002534df.pdf (accessed on 16 August 2021).

Allard, Pierre, and Wayne Northey. 2001. Christianity: The rediscovery of restorative justice in the spiritual roots of restorative justice. In The Spiritual Roots of Restorative Justice. Edited by Michael L. Hadley. New York: State University of New York.

An, Jing. 2017. Research on the Civil Disputes Private Relief-A Case Study of the Civil Dispute Resolution in the Tibetan Folk. Paper presented at the 2017 International Conference on Innovations in Economic Management and Social Science, Hangzhou, China, 15-16 April 2017.

Adamczyk, Amy, Joshua D. Freilich, and Chunrye Kim. 2017. Religion and crime: A systematic review and assessment of next steps. Sociology of Religion 78: 192-232. [CrossRef] 
Ahmed, Ali M. 2009. Are religious people more prosocial? A quasi-experimental study with Madrasah pupils in a rural community in India. Journal for the Scientific Study of Religion 48: 368-74. [CrossRef]

Angela, C. Carmella. 2010. Religion-Free environments in common interest communities. Pepperdine Law Review 38: 57-110.

Batson, C. Daniel. 2012. A history of prosocial behavior research. In Handbook of the History of Social Psychology. Edited by Arie W. Kruglanski and Wolfgang Stoebe. London: Psychology Press.

Braithwaite, John. 2009. Restorative justice. In International Handbook of Criminology. Edited by H. J. Schneider. Berlin: Walter de Gruyter.

Brunk, Conrad G. 2001. Restorative justice and the philosophical theories of punishment. In The Spiritual Roots of Restorative Justice. Edited by Michael L. Hadley. New York: State University of New York.

Bush, Robert A. Baruch, and Joseph P. Folger. 1994. The Promise of Mediation: Responding to Conflict through Empowerment and Recognition. Sancisco: Jossey-Bass Publishers.

Cai, Rang. 2007. 吐蕃史稿 (History of Tubo Dynasty). Gansu: Gansu People's Publishing House.

Chen, Jinquan. 2008. 刑事习惯法 (Criminal customary rules). In 西南少数民族习惯法研究 (Study on Folk Norms of Ethnic Minorities in Southwest China). Edited by Jinquan Chen, Zhicheng Pan and Ling Yang. Beijing: Law Press.

Clear, Todd R., and Melvina T. Sumter. 2002. Prisoners and religion: Religion and adjustment to prison. Journal of Offender Rehabilitation 35: 125-56. [CrossRef]

Cunneen, Chris, Jocelyn Luff, Karen Menzies, and Nina Ralph. 2005. Indigenous family mediation: The New South Wales ATSIFAM program. Australian Indigenous Law Reporter 9: 1-14.

Durkheim, Emile. 1951. Egoistic suicide. In Suicide a Study in Sociology. New York: The Fire Press.

Ekvall, Robert B. 1954. Mi sTong: The Tibetan custom of life indemnity. Sociologus 4: 136-45.

Ekvall, Robert B. 1964. Peace and war among the Tibetan nomads. American Anthropologist 66: 1119-48. [CrossRef]

Ekvall, Robert B. 1968. Fields on the Hoof: Nexus of Tibetan Nomadic Pastoralism. Long Grove: Waveland.

Ellickson, Robert C. 2003. Order Without Law: How Neighbors Settle Dispute. Translated by Li Su. Beijing: University of Political Science and Law Press.

Ellison, Christopher G., and Linda K. George. 1994. Religious involvement, social ties, and social support in a southeastern community. Journal for the Scientific Study of Religion 33: 46-61. [CrossRef]

Ellis, Lee. 2002. Denominational differences in self-reported delinquency. Journal of Offender Rehabilitation 35: 179-92. [CrossRef]

Fang, Yeyuan. 2017. 刑事和解在少数民族地区的地方化构建 (Localization of Victim-offender mediation in Ethnic Minority Areas). Journal of Northeast Normal University 5: 51-57.

Galanter, Marc. 1981. Justice in many rooms: Courts, private ordering, and indigenous law. Journal of Legal Pluralism 19: 17-21. [CrossRef]

Graybill, S. Lyn. 2017. Religion, Tradition, and Restorative Justice in Sierra Leone. Notre Dame: University of Notre Dame Press.

Gedicks, M. Frederick. 2003. Restorative justice and the two-tack establishment clause. Utah Law Review 523. Available online: http:/ / www.antoniocasella.eu/restorative/Luna_2003.pdf (accessed on 16 August 2021).

Greenwood, J. H. Daniel. 2003. Restorative justice and the Jewish question. Utah Law Review 533. Available online: https:// scholarlycommons.law.hofstra.edu/cgi/viewcontent.cgi?article=1327\&context=faculty_scholarship (accessed on 16 August 2021). [CrossRef]

Gumz, Edward J., and Cynthia L. Grant. 2009. Restorative justice: A systematic review of the social work literature. Families in Society 90: 119-26. [CrossRef]

Hadley, Michael L, ed. 2001. The Spiritual Roots of Restorative Justice. New York: State University of New York.

Hascall, C. Susan. 2011. Restorative justice in Islam: Should Qisas be considered a form of restorative justice? Berkeley Journal of Middle Eastern $\mathcal{E}$ Islamic Law 4. [CrossRef]

Hirschi, Travis, and Rodney Stark. 1969. Hellfire and delinquency. Social Problems 17: 202-13. [CrossRef]

Huyse, Luc, and Mark Salter. 2008. Traditional Justice and Reconciliation after Violent Conflict-Learning from African Experiences. Stockholm: International IDEA.

Johnson, Byron R., Sung Joon Jang, Davod B. Larson, and Spencer De Li. 2001. Does adolescent religious commitment matter? A reexamination of the effects of religiosity on delinquency. Journal of Research in Crime and Delinquency 38: 22-44. [CrossRef]

Johnson, Byron R. 2012. More God, Less Crime: More God, Less Crime: Why Faith Matters and How It Could Matter More. West Conshohocken: Templeton Press.

Johnson, Byron R. 2021. How religion contributes to the common good, positive criminology, and justice reform. Religions 12 : 402. [CrossRef]

Jang, Sung Joon, and Byron R. Johnson. 2017. Religion, spirituality, and desistance from crime: Toward a theory of existential identity transformation. In The Routledge international Handbook of Life-course Criminology. Edited by Arjan Blokland and Victor van der Geest. New York: Routledge.

Jang, Sung Joon, Byron R. Johnson, Joshua Hays, Michael Hallett, and Grant Duwe. 2018. Religion and misconduct in "Angola" prison: Conversion, congregational participation, religiosity, and self-identities. Justice Quarterly 35: 412-42. [CrossRef]

Jones, Mark, and Barbara Sims. 2016. Reintegrative shaming, redemption, and acceptance: A survey of Christian church goers in eastern North Carolina. Journal of Ethnicity in Criminal Justice 14: 348-70. [CrossRef] 
Junger, Marianne, and Wim Polder. 1993. Religiosity, religious climate, and delinquency among ethnic groups in the Netherlands. British Journal of Criminology 33: 416-35. [CrossRef]

Kerley, Kent R. 2014. Religious Faith in Correctional Contexts. Boulder: First Forum Press.

Kelsall, Tim. 2005. Truth, lies, ritual: Preliminary reflections on the Truth and Reconciliation Commission in Sierra Leone. Human Rights Quarterly 27: 361-91. [CrossRef]

Kohen, Ari. 2009. The personal and the political: Forgiveness and reconciliation in restorative justice. Critical Review of International Social and Political Philosophy 12: 399-423. [CrossRef]

Liu, Mingxing, and Ran Tao. 2007. Local governance and fiscal reform. In Paying for Progress in China. Edited by Vivienne Shue and Christine Wong. London: Routledge.

Misleh, Daniel J., and Evelyn U. Hanneman. 2003. Emerging issues: The faith communities and the criminal justice system. Journal of Religion and Spirituality in Social Work 23: 111-31. [CrossRef]

Morag, Michal, and Elly Teman. 2018. The "watchful eye of God": The role of religion in the rehabilitation and reentry of repentant Jewish prisoners. International Journal of Offender Therapy and Comparative Criminology 62: 2103-26. [CrossRef]

Muchi, Yundeng Jiacuo. 2013. “活法”密码一藏族习惯法”董嘉哇”制度生命力探究 (Code of “Living Law”: On the Vitality of the Tibetan Folk Norms of “Dongjiawa” System). Journal of Folk Norms 12: 229-41.

Murithi, Tim, and Paula Murphy Ives. 2007. Under the Acacia: Mediation and the Dilemma of Inclusion. Available online: https:/ / www.hdcentre.org/wp-content/uploads/2016/08/108UndertheAcacia_Mediationandthedilemmaofinclusion-April-2007.pdf. (accessed on 18 August 2021).

Pirie, Fernanda. 2005. Segmentation within the State: The reconfiguration of Tibetan tribes in China's reform period. Nomadic Peoples 9: 83-102. [CrossRef]

Pirie, Fernanda. 2006. Secular morality, village law, and Buddhism in Tibetan societies. Journal of Royal Anthropological Institute 12: 173-90. [CrossRef]

Pirie, Fernanda. 2008. Violence and opposition among the nomads of Amdo: Expectations of leadership and religious authority. In Conflict and Social Order in Tibet and Inner Asia. Edited by Fernanda Pirie and Toni Huber. Leiden: Brill.

Pirie, Fernanda. 2013. The limits of the state: Coercion and consent in Chinese Tibet. Journal of Asian Studies 72: 69-89. [CrossRef]

Reisig, Michael D., Scott E. Wolfe, and Travis C. Pratt. 2012. Low self-control and the religiosity-crime relationship. Criminal Justice and Behavior 39: 1172-91. [CrossRef]

Ritzer, George, and Jeffrey Stepnisky. 2017. Emile Durkheim. In Sociological Theory, 10th ed. Thousand Oaks: Sage Publications.

Ronel, Natti, and Ety Elisha. 2011. A different perspective: Introducing positive criminology. International Journal of Offender Therapy and Comparative Criminology 55: 305-25. [CrossRef]

Ronel, Natti, and Dana Segev. 2015. Positive Criminology. New York: Routledge.

Ross, Lee E. 1994. Religion and deviance: Exploring the impact of social control elements. Sociological Spectrum 14: 65-86. [CrossRef]

Ross, Lee E. 1996. The Relationship between religion, self-esteem, and delinquency. Journal of Crime and Justice 19: 195-214. [CrossRef]

Ross, Lee E. 2021. Prisoner reformation and the promise of religion. Religions 12: 105. [CrossRef]

Sarre, Rick T, and Young Janette. 2011. Christian approaches to the restorative justice movement: Observations on scripture and praxis. Contemporary Justice Review: Issues in Criminal, Social, and Restorative Justice 14: 345-55. [CrossRef]

Scott, James C. 1997. Seeing Like a State: How Certain Schemes to Improve the Human Condition Have Failed. New Haven: Yale University Press.

Segal, Eliezer. 2001. Jewish perspectives on restorative justice. In The Spiritual Roots of Restorative Justice. Edited by Michael L. Hadley. New York: State University of New York.

Silliman, Sidney G. 1985. A political analysis of the Philippines' Katarungang Pambarangay system of informal justice through mediation. Law \& Society Review 19: 279-302.

Shin, W. Mama. 2020. Keep walking for peace and justice: Gender violence and Liberian mothers' interreligious peace movement. Religions 11: 323. [CrossRef]

Sullivan, Dennis, and Larry Tifft. 2001. Restorative Justice: Healing the Foundations of Our Everyday Lives. New York: Willow Tree.

Sumter, Melvina, Frank Wood, Ingrid Whitaker, and Dianne Berger-Hill. 2018. Religion and crime studies: Assessing what has been learned. Religions 9: 193. [CrossRef]

Suonan, Cairang. 2004. 藏族历代法典 (Law Codes in Tibetan History). Beijing: The Ethnic Publishing House Press.

Tanase, Takao. 2004. Dispute Resolution and Judicial System. Translated by Yaxin Wang. Beijing: China University of Political Science and Law Press.

Ulmer, Jeffery T., and Chasey T. Harris. 2013. Race and the religious contexts of violence: Linking religion and white, black, and latino violent crime. The Sociological Quarterly 54: 610-46. [CrossRef]

United Nations Office on Drugs and Crime. 2006. Handbook on Restorative Justice Programmes. Available online: www.unodc.org/pdf/ criminal_justice/06--56290_Ebook.pdf (accessed on 26 August 2021).

Van Ness, D. W. 2005. An overview of restorative justice around the world. In Workshop 2: Enhancing Criminal Justice Reform Including Restorative Justice, at the Eleventh United Nations Congress on Crime Prevention and Criminal Justice. Paper presented at the Eleventh United Nations Congress on Crime Prevention and Criminal Justice, Bangkok, Thailand, April 22. Vienna: UNODC.

Weitekamp, Elmar G. M., and Hans-Jürgen Kerner. 2002. Restorative Justice: Theoretical Foundations. London: Willan Publishing. 
Wilson, Richard. 2001. The Politics of Truth and Reconciliation in South Africa: Legitimizing the Post-apartheid State. Cambridge: Cambridge University Press.

Yeh, Emily T. 2000. Forest claims, conflicts and commodification: The political ecology of Tibetan mushroom-harvesting villages in Yunnan Province, China. The China Quarterly 1: 264-78. [CrossRef]

Yeh, Emily T. 2003. Tibetan range wars: Spatial politics and authority on the grasslands of Amdo. Development and Change 3: 499-523. [CrossRef]

Zehr, Howard. 1990. Changing Lenses: A New Focus for Crime and Justice. Windsor: Herald Press.

Zehr, Howard. 2002. The Little Book of Restorative Justice. Brattleboro: Brattleboro Good Books.

Zehr, Howard, and Barb Toews. 2004. Critical Issues in Restorative Justice. New York: Criminal Justice Press.

Zhang, Jimin. 2002. 诸说求真一藏族部落习惯法专论 (Seeking Truth from Statements—A Monograph on Customary Rules in Tibetan Tribes). Xining: Qinghai People's Publishing House.

Zhou, Shizhong. 2015. 民族习惯法在西南民族地区司法审判中的适用研究 (Study on the Application of Ethnic Folk Norms in the Judicial Trial in Ethnic Minority Areas in Southwest China). Beijing: Law Press. 